\title{
Sonic 2: bigger than Madonna
}

Jeux vidéos pour enfants

\section{Catherine Hillman-Steven}

\section{(2) OpenEdition}

\section{Journals}

Electronic version

URL: http://journals.openedition.org/asp/4326

DOI: $10.4000 /$ asp.4326

ISSN: 2108-6354

Publisher

Groupe d'étude et de recherche en anglais de spécialité

\section{Printed version}

Date of publication: 1 October 1993

Number of pages: 371-387

ISSN: 1246-8185

\section{Electronic reference}

Catherine Hillman-Steven, « Sonic 2: bigger than Madonna », ASp [Online], 2 | 1993, Online since 07 March 2014, connection on 19 April 2019. URL : http://journals.openedition.org/asp/4326 ; DOI : $10.4000 / a s p .4326$

This text was automatically generated on 19 April 2019

Tous droits réservés 


\title{
Sonic 2: bigger than Madonna
}

Jeux vidéos pour enfants

\author{
Catherine Hillman-Steven
}

\section{Introduction}

1 The Daily Mirror described the new video game Sonic 2 thus:

It's new, it's mega, it's bigger than Madonna!

2 The video games company Sega launched its advertising campaign for the sale of its second video game featuring its already famous hero, Sonic 2, in November 1992. Within a week sales had surpassed even the wildest predictions and the Daily Mirror ran a front page advertisement to win a Sonic game carrying the following extravagant headline:

Sonic 2, we've got 50 to give away

3 The headlines of the same page resume the preoccupation of the public to counterbalance the ill effects of the recession, carrying stories of the Royal Family and their unwillingness to pay tax or the repair bills for Windsor Castle (cf. headline):

Unfair ma'am

Exclusive: who'll pay my bill?

4 The three main topics suggest what is uppermost in the public mind: Sonic - Fun and games; The Queen - Gossip and scandal; Madonna - Sex and fantasy.

5 If we consider that the preoccupation with the lives of the Royal Family remains the pastime of those with nothing better to do than live a super soap by proxy, we may also consider the implications of the social preoccupations which the popularity of Sonic and Madonna suggest.

6 Madonna is the singer and the sex symbol. To enhance her image further and enlarge her fortune, she produced a book for the Christmas market and explicitly entitled it Sex. Perhaps the market was already sufficiently saturated by her films and steamy videos to take to the more tedious pastime of reading or turning pages. Be that as it may, Sex was a commercial flop. Although it was forbidden eventually in the Republic of Ireland, it had 
been far from a sell-out before censorship. In Paris, New York and London sales were very slow after the initial first day rush.

The big market shift has been to video games. As far as sex and fantasy are concerned there is plenty to be found on the computer game market. Involvement on the part of the player is far greater than passive watching or listening and therefore the games industry has out-stripped the record and book industry in the Christmas shopping rush.

8 Computer games have replaced some of the more traditional pursuits because they encompass and surpass the pleasure derived from them.

The biggest selling album this year will be Simply Red's Stars but we will make more money out of Streetfighter 2 alone. (Mike Hayes, Nintendo's distributor in the UK)

Sega and Nintendo are the two biggest computer games distributors in the world. Rival Japanese firms, they battle for the world market. They have dominated Christmas sales for the second year running in the UK. The estimated market value is $£ 500 \mathrm{~m}$, around half the total toy market. Nintendo says that around a million of its products are bought as presents while Sega claims that its premium product, the Sega Megadrive, is the best selling single item.

Nintendo's $€ 350 \mathrm{~m}$ turnover is split equally between hardware and software, but next year we expect software to be more important, with the emphasis nearer 60/40. (Mike Hayes)

10 N. Alexander, head of Sega Enterprises in the UK, says the company's performance in December was "phenomenal" and "exceeded even our own expectations". He claims that overall, Sega sales could reach $£ 375 \mathrm{~m}$ for the year, sales of Megadrive nearing one million units. Some UK estimates say that software sales could reach $£ 650 \mathrm{~m}$ across the sector. This compares with the compact disc market estimated at $£ 345 \mathrm{~m}$. The CD market itself is the lifeline to the traditional record-cassette market which is floundering.

11 Although the article remains pricey, availability is guaranteed to the young and the poor through renting facilities of both software and hardware in video shops. A Glasgow social worker told us that video games were the biggest single cause of petty crime in the city, where children would beg, borrow or racket and steal to obtain a new game.

They will lock themselves in the high rise flats with their games and MTV and dog school until the game's out. They're addicts.

12 There is reason to believe that there is a certain danger to health, which seems inevitable if a child spends hours in front of a screen without supervision, to his sleep or exercise, without mentioning his mental health, considering the violent nature of certain games.

Addiction to the fantasy experience of the video game is held responsible for many social ills, classroom chaos ranking high among them, as a milder form of juvenile delinquency. But as children are exposed to so many forms of violent fiction and fantasy within a realistic scenario, their awareness of what is right or wrong can be seriously endangered.

14 Kenneth Clarke, the Home Secretary, answered the public outcry over the murder of a two-year-old boy by two other ten-year-olds (the media reported that the boys played unconcerned with hand-held video games while waiting to go into Court), by imposing stricter measures on juvenile delinquents. John Major ordered a "crusade" against juvenile crime, whilst the Archbishop of York, John Habgood, replied that it was the reasons for crime that had to be fought against, the deterioration of the social thread, especially unemployment: 
The Government has emphasised the need to strive for success through competition, encouraging the assumption that we are all fighting against one another.

15 John Major insists that there should be a return to the old priorities of the educational system which was based on the 3Rs, except now there will be 5Rs - Reading, 'Riting, 'Rithmetic, Right and 'Rong.

But while the debate on the moral education of our children continues, Sega and Nintendo's campaign to hook them into the video world of fantasy and violence, horror and power struggles goes on. Once the child has a piece of hardware and a game, no matter how seemingly harmless Sonic 2 or Fantasia appear for example, they are a simple step away from the fun experienced in the hard-core violence and the nasties boasted about by their slightly older peers. Once the children have mastered the controls of the simple games they step up the speed and the difficulty immediately, the challenge and the excitement is irresistible. The drive and the need to dominate (i.e., to win) can surpass the high of the playing field, the football pitch, academic success and, during adolescence through to adulthood, the sexual experience.

17 We shall present and comment upon French and British television and press advertisements and the language used in the same.

\section{Nintendo Gameboy game Prince Vaillant}

(30 seconds, during the T.V. showing of Tintin au Pays de l'Or Noir in November)

A boy of twelve presents the start button on his Gameboy and takes off, clothed in Prince Vaillant costume. His Gameboy becomes a sword and he is shown in combat with armies of cartoon soldiers and prehistoric monsters.

Je suis Prince Vaillant.

Enfin en jeu vidéo, le héros du dessin animé Prince Vaillant.

Dans ce jeu j'affronte tous les ennemis. Je cours tous les dangers.

Je combats les monstres les plus effrayants."

Prince Vaillant : sur Gameboy et console Nintendo. Jeu vidéo Ocean.

Tu es pris au jeu.

This is probably the tamest video advertisement viewed on TV that season. It is probably a general parental assumption that the Gameboy is little more than a sophisticated game gadget: harmless in as far as it could be easily pocketed and forgotten by the owner, or even confiscated at will by parents or teachers - harmful in as far as it can easily be concealed and stolen, habit-forming away from parental control. The ambiguity of this punchline to another TV advertisement for Gameboy speaks volumes.

\section{Gameboy}

Where do you play with yours?

A boy hides in a phone box and is seen in a state of ecstasy apparently having scored on his machine. Habit forming is the first step to addiction.

Tu es pris au jeu. You are under a spell. It's got you now.

21 We already mentioned the very rapid ascension from the benign to the nasty. Probably the Gameboy is the first step. Although an expensive item, (costing around £50), it is still 
greatly coveted and obtained by junior enthusiasts. It is at the bottom of the price range but once the child, from 7 upwards, has mastered the controls, he is ready for higher excitement on the big screen, i.e. the TV. Both Nintendo and Sega cater for the wildest desires at all prices and monopolize the market. Many other specialists promote hardware compatible with their software. They take royalties of around $10 \%$ on computer hardware and nearly $40 \%$ on software. A game which costs $£ 40$ may only cost $£ 5-£ 10$ to make. A parental lobby in the USA is fighting action against Nintendo over the restrictive licensing of software.

\section{Nintendoscope}

(20 seconds, November 1992 - £160)

The more expensive range from Nintendo is advertised featuring an older child with a more fashionable trendy approach to a very expensive toy. He has longer hair, jeans gear and has a look of adolescent awareness, as opposed to the first who dreams of being a prince.

This time the protagonist carries a weapon the size of a heavy machine gun on his shoulder. He is aiming at a graphic enemy on a set of four screens.

Nintendoscope - tirez par infra rouge!

La précision laser est au pixel près.

Avec 6 super jeux - la technologie du nintendoscope fait de vous un tireur d'élite.

The boy becomes so confused by the realistic effect of the game that he is shown fumbling for the glass in his hand outstretched, dazed at his own performance. This itself might be a warning to parents about the addictive feature of the game, but for the same reasons this makes the game more attractive to children. As there is no obvious conventional social evil involved in the harmless play there can be no real censorship of it. However, it might be worth considering the consequences of offering a tool which would enable a young person to become a sharp shooter within his own home.

\section{Amiga computer hardware}

The scenario looks like deserted Gotham City at night. Shades of purple; black and grey. There is no dialogue, but plenty of heavy metal suspense music. A Terminator-style robot in black leather appears with eyes that light up red, indicating that he has located his prey. He is bristling with wreaths of ammunition wound around him and is armed to the teeth.

Meanwhile nearby in a penthouse flat in a clinically aesthetic black and white interior, a young man (pre-yuppy style, with short hair and glasses) is seated in front of a computer. He has located the enemy who is approaching fast. He is concentrating.

Over a hundred children from 12 - 16 consulted, spoke of him with admiration.:

He is rich, classy, intelligent, a brilliant player, in control, typically American. And of the robot:

You just want to destroy him, smash him to bits... that's what it's all about.

The crucial moment of the game is highlighted in the ad as the robot smashes down the door and the boy accelerates his keyboard skills and succeeds in disintegrating him. He 
has won the game. All through the ad, we see almost subliminal flashes of the graphics of the Terminator game.

The punchline runs the challenge:

Have you got what it takes?

\section{Megadrive} bullying, condescending:

Bienvenue chez Maître Sega - Tu veux jouer à Terminator sur Mega drive? - Micro processeur 16 bits - son stereo, 72 couleurs

A car smashes through a brick wall. Another leather-clad (Terminator) figure approaches a console pivoted to a revolving control panel in the middle of a bare stone pit. He is obviously intent on destruction - he is the enemy you are pitting your wits against.

Flashes of the game graphics show what you actually get with the game while the robot starts to disintegrate. The excitement may make you lose your head and you could end up like the robot - melted down to nothing. A mental short circuit? The voice is merciless.

Alors petit, tu as les fils qui se touchent?

Sega, c'est plus fort que toi.

The same language is used for Sonic 2, but there is no elaborate scenario as in the preceding ads. Sonic's fame was made before, and the addicts could not wait to buy it. As we said above, it was an immediate sell-out. In this ad we are only given a sample of the graphics, the language remains the same:

Serez -vous assez fort pour maitriser Sonic 2 ?

Mega graphics - mega couleurs - mega vitesse

Si tu as l'impression d'etre suivi, c'est normal, on peut jouer à deux.

Sega, c'est plus fort que toi.

This ad was sandwiched between ads for Barbie dolls and Fisher Price trucks on peakviewing children's programme in December 1992.

\section{Jack the Joker} He suddenly takes off to the sound of deafening music. He is clutching giant syringes and The above title is flashed on the screen in American handscript in bright yellow letters on
a purple background, and reads "Fuck the Joker". This ad features an adult (couch potato
style) dressed in technicolour clothes sitting dreaming, in what looks like a barber's chair. instruments of torture. "The Barber" appears dressed also in psychedelic clothes and an enormous red bow-tie screaming at his victim and brandishing an enormous vibrating electric hacksaw. The barber and the customer are the same person. The graphics of a Batman battle scene flash on the screen with the price of $£ 39.99$ and Sega in giant letters, followed by Batman Returns and a full screen Batman Gold Crest.

The barber is now grooving fast and dancing like Mike Jagger, into the swing of the games. He clashes his instruments like maracas and streets of rage graphics start flashing. Voice over the loud music screams:

Wipe the floor with evil doers 


$$
\begin{aligned}
& \text { man in the barber's chair appears with closed eyes seemingly unconscious. The barber } \\
& \text { pulls a cord from behind his neck as if to wind him up again and his eyes open and start } \\
& \text { to spin in their orbits. The barber sprays all around with a machine gun that is } \\
& \text { controlling him. The screen flashes in huge letters: } \\
& \text { To be this good takes ages (which turns into Sega backwards) } \\
& \text { Graphics of Streets of Rage and Mutant Turtles flash to the soundtrack: } \\
& \text { You want to clean up the pong in the sewers or wipe the floor with evil doers? } \\
& \text { A crash precedes the final orgasmic message, coaxing defiantly: } \\
& \text { If you're gonna play these Sega games - you need more power than guts. }
\end{aligned}
$$

\section{Video games programmes}

Ads for video games programmes carry the same message:

From the vast expanses of games technology comes the ultimate in arcade adventure. Enter the games world on a galaxy of survival levels. Preview the latest technical breakthroughs and experience new frontiers in games' advancement. Then you make your fiercest encounters against the mighty Videotors.

\section{Supernintendo entertainment system}

\section{Game: Super Mario Kart, No faster fun on wheels}

Computer and video games magazine: Double page ad in black and white, across the double page a close-up of the piercing eyes of a clean-cut tough guy stare out at the reader, challenging him to play.

In three-cm high letters this onomatopaeic message invites the reader to the language of thoughts and emotions confined into a word form expressing an only half-formulated idea. The speed of the karting experience defies conventional language codes:

greasy granite

spikeless thwomps (spineless wimps, pikeless swamps, spike less thumps, swipe the like.

The list and interpretation of word fabrication could go on ad infinitum. "Loose dirt" (pun on lose the nasties, get rid of your evil impulses, i.e. take off with us).

The punchline always resumes the challenge, on the right-hand page, in the bottom corner:

Will you ever reach the end?

\section{Woolworth's} about the dinosaur's eggs.

Try a spell in Woolworth's... wipe yourself down, head for any branch and feed your face with all the latest hard and software. (Sega at Woolworth's)

Advertising in the same magazine as above, Woolworth's plugs both Sega and Nintendo.

Sega's carries a boy with an enormous green egg smashing vomit on his face.

You melted the dragon... vaulted the drawbridge. waded the swamp, and forgot

The colours in the second are particularly garish purple, pink background featuring a long subhuman head from which protrudes a mushroom covered tongue. 
Overdosed on gravity rays? Down to your last energy bar? And plagued by mushrooms? photographs. They all carried the same message.

C'est fou ce qu'on faisait avant le megadrive

\section{Toys 'R' Us}

It's a tidal wave of titles.

\section{Video games} experience. chopper in your hands. provides you with plenty of Communist cannon fodder.

James Bond Jr tootling craft into a speed demon!

\section{Streetfighter 2}

\section{Sega Megadrive} making).

\section{Sega game gear}

(Double-page glossy video magazine, September 1992)

Check yourself into Woolworth's. All the latest cures for hard and software addicts, currently available on prescription at every branch. (Nintendo at Woolworth's)

A few pages later two 7-year-olds smile out in childish delight from a mountain of video games. The visible titles are tame enough not to deter the parent buyer: Knight Rider, Super Mario 3, Skate or Die, Winnie the Pooh, Link, Archon, Super Tennis, Demon Sword.

Choose from hundreds of Nintendo and Sega video games. (Toys ' $R$ ' Us)

We have selected some of the terms used to entice the player into a new flying

Comanche as easy as kgb - death from above - Commies on the starboard bow - a

The following explanation of the game merits some attention.

Despite the end of the cold war and the break-up of the Soviet Union, the programmers of Comanche Maximum Overkill have managed to find a plot which

Ian Fleming might be surprised to hear the explanation of the game.

The original James Bond always wooed the lovelies with his wealth of hi-tech kit, and his young un looks to be following in his father's footsteps. Get hold of grenades for long distance lobbing; or grab the rocket gun for enemy shooting action or thrills. In the air, pick up the shrapnel-tipped missiles to destroy many more vehicles, and, on the speedboat level, purloin the nitreo boost to turn your

See if you've got what it takes to become the ultimate World Warrier

Sega launched a national bill board campaign using blow-ups of old black and white ne billboard showed groups of hippies smoking pot (non aggressive behaviour)?

Another showed groups of demonstrators throwing cobbles at CRS during the 1968 riots. (aggressive behaviour). A third showed a couple of twenties-style lovers kissing (love- 
Another look-alike black and white photo from the 1968 riots in Paris. But this time the hero is not the student demonstrator but the steel helmeted riot policeman, ready to charge. In the heat he gasps:

j'suis paumé la ...... c'est quel bouton déjà pour sauter?

The usual Sega punchline follows:

Game gear. Où que tu sois c'est plus fort que toi. Sega.

What caused excitement in the past can only be considered as tame or boring or quite mad, as Sega informs. The world in which hi-tech video games are a sublime form of diversion and entertainment is indeed a realm of fantasy in which time and space are experienced through the medium of the machine: there are no limits to what the imagination can create. The ultimate aim is to make the game as realistic as possible. (The virtual experience is one in which you don a helmet and/or glasses and you have a 3D perception of the game you enter physically). (Sega also sells a moving carpet on which you can run on the spot and feel you are running after the enemy in the game). In extreme cases, and especially in gameplay overdosing, confusion between the trip and reality is frequent. Cases of epilepsy have been reported in the UK, triggered off by overexposure to the light from the screens.

\section{Sega}

We have been fortunate to obtain an unedited ad made by Sega to promote their products. This is a far cry from what is actually shown on TV. It is no longer uncut, but its length and certain details make interesting food for thought concerning the education of children, as play is considered to be an essential part of their character building.

Again the scenario is an aesthetically clinical apartment in which the sparse furniture is clean cut and of steel and leather. A bird is sleeping in a cage. Goldfish swim in a tank. A window with a cross-shaped frame shows an empty clear sky. The man is a model with long hair and good looks, dressed in a white shirt and leather pants. Religious hi-fi music floods his entrance. He moves to the leather divan/chair and lies back.

A sexy girl's voice addresses him:

Do you remember the old days, the days of mono entertainment, before Sega brought in the ultimate games console? That changed everything...

A change in music, harsher unmelodious sounds move into metallic hacking noises as the screen shows sub-humans or half robots digging at a cracked planet surface and discovering a megadrive plug. The scene is of a Sci-Fi wilderness. The creatures brighten up and come to life as the machine starts. Giant goldfish spring from the cracks in the earth. A battle with the monsters is fought and won. Sci-fi wondrous dawn music is cut into by the sexy voice again:

The sega megadrive: the first machine to give you access to 16 bit technology, dedicated to pure game play.

63 The man has closed his eyes and the bird is now agitated. The music starts livening up into hard rock. Game graphics are flashing as the voice informs:

The first machine to give you full colour graphics detailed animation. approaches the man on the couch: 
So where do you go from here? What are you going to do with all that imagination of yours?

The journey starts here, this little baby is only the tip of the iceberg.

The story continues with:

She walks round the chair as he lies listening and graphics of video games start flashing. The man grips the steel bar of his chair as if to change gear and the music changes back to religious harmony before as her voice cajoles and then straight back into hard rock as the bird in the cage screeches and leaps into the air. Graphics of games show on the screen.

imagine a machine with over 500 megabites of power - two 16 bit processors and enough capacity to use real film imagery - cd quality sound.

The bird's screech is a monster's voice

Add a mega cd and turn your megadrive into a monster.

The girl caresses his leg and informs him:

When you bought your megadrive you bought your ticket to ride. - blow your mind with the ultimate peripheral to your megadrive. - only the megadrive can give you such awesome games play.

7 The girl leaves him to kneel in front of the TV screen. She is sucked into it as the music moves back into hard rock, almost heavy metal as she leaves him with the parting words:

I am your passport to the future

Sega puts the video in video games

The age-old paradox of man controlling woman who really controls man becomes obsolete as it is the machine which controls them both. Two minutes are given to show the fast action of the video game with scenes from horror films integrated into the video CD. The hard music begins, the man clutches his chair as the game (and he) takes off. Nothing comes nearer to the bad trip:

dogmeaI - relax, pretend it's a game - you have reason to live - freak out, get him, dogmeat - we got a one way ticket to vicious and aggressive commands - catwoman - i'm catwoman, give me more ETC. - vampire - we all have our very special craving tonight - protect these girls from whatever happened to the other ones.

(screen flash, no voice):

full image rotation and scrolling

mega cd games contain these real film images

Horror scenes make the tension rise as scenes of Cobra Command and Batwoman and Night Trap are shown and the player participates in the role game of killer or hunted. Plans of the apartment are given and the music gets louder and louder as we see girls tortured or violated by robots. The voice pushes the ultimate in hi-tech a step further:

Sega puts the video into video games so make your own video

One shudders to think what the creative power of the player would be after game absorption in some of the above games. The ad addresses itself to the younger generation of music lovers, however, who would be enthusiastic about submitting their home made clips to MTV.

1 Harmless Kriss Kross appears to rap music. Messages start flashing on the screen to the beat:

video, plus, creativity, plus special fx [effects], make your own music video

Scenes of black children break-dancing and grooving to rap music makes the invention a good idea for show business hopefuls.

kriss kross : that's gonna end up on m.t.v. or some place for sure. 

steel bars and sweating in his sleep. A resounding final crash awakens him and the bird in the cage collapses in exhaustion. The voice floods in on his post trip musings:

and if you're not ready for mega cd play ability, chill out on your own music. forces are unleashing monsters which can be harmful, especially to children. Jung said that deep down we have dynamic instinctive forces necessary to complete our personalities. Awareness means coming to terms with them and not smothering or hiding from them. In human development this awareness is the facing of the shadow which is our subconscious, what we do not want to admit about the negative in ourselves. You have to look inwards to find the light and the shadow and come to terms with it. Watching a screen and the game or drug experience is a trip away from self awareness, a substitute for self discovery.

is a very grave danger to games addiction. If the machine controls the player, and the younger the player the graver the danger, rehabilitation, as with drug abusers, is longer and more difficult. Who then can explain right and wrong, good and evil, fiction and reality. Only time will tell if it is even at all possible. We do not yet know what our video game warriors will produce in the future.

The Archbishop of York appeals for the re-establishing of traditional values in child raising in the attempt to avoid juvenile delinquency, i.e. the flip side of evil: encouraging sensitivity, consciousness, evolution; autonomy, free-will. The only rule which prevails in the video game world is power, the will to dominate, manipulate, control and/or destroy.

\section{BIBLIOGRAPHY}

Bell, Emily. 1992. "Carsberg takes on the Game Boys”. Sunday Observer 4th December.

Berliner, Wendy. 1993. “Coke? That's a drink isn't it?”. Guardian Education 23rd February.

Daily Mirror. 1992. “It's New, It's Mega” 3rd November.

Fromm, Erich. 1975. La passion de détruire: anatomie de la destructivité humaine. Transl. By Théo Carlier. Paris: Laffont.

Reuter. 1993. "Le livre de Madonna interdit”. Le Monde 21st January.

Zeccin, L. 1993. “L'Archêveque d'York met en cause la politique de répression de la criminalité juvenile”. Le Monde 2nd March. 


\section{ABSTRACTS}

Video games can be a danger to the child who becomes addicted to them. They have surpassed the popularity of tamer entertainment for children, like sports and pop music, because of the thrills and adult experiences they guarantee.

Les jeux vidéo sont un danger potentiel pour l'enfant qui en devient dépendant. Ils ont dépassé en popularité les loisirs plus bénins pour enfants, comme le sport et la musique pop, à cause des frissons et des expériences de type adulte qu'ils garantissent.

INDEX

Mots-clés: publicité, Nintendo, Sega

Keywords: advertising

\section{AUTHOR}

\section{CATHERINE HILLMAN-STEVEN}

Institut d'Administration des Entreprises de Basse-Normandie, Université de Caen. 